\title{
Overlapped feeds to increase the edge of coverage gain in multi-beam reflector antennas
}

\section{Citation for published version (APA):}

Llombart, N., Neto, A., Gerini, G., Bonnedal, M., \& de Maagt, P. J. I. (2007). Overlapped feeds to increase the edge of coverage gain in multi-beam reflector antennas. In Proceedings of IEEE Antennas and Propagation Society International Symposium, 2007, Honolulu, 9-15 June 2007 (pp. 5664-5667). Institute of Electrical and Electronics Engineers. https://doi.org/10.1109/APS.2007.4396835

DOI:

10.1109/APS.2007.4396835

Document status and date:

Published: 01/01/2007

\section{Document Version:}

Publisher's PDF, also known as Version of Record (includes final page, issue and volume numbers)

\section{Please check the document version of this publication:}

- A submitted manuscript is the version of the article upon submission and before peer-review. There can be important differences between the submitted version and the official published version of record. People interested in the research are advised to contact the author for the final version of the publication, or visit the $\mathrm{DOI}$ to the publisher's website.

- The final author version and the galley proof are versions of the publication after peer review.

- The final published version features the final layout of the paper including the volume, issue and page numbers.

Link to publication

\section{General rights}

Copyright and moral rights for the publications made accessible in the public portal are retained by the authors and/or other copyright owners and it is a condition of accessing publications that users recognise and abide by the legal requirements associated with these rights.

- Users may download and print one copy of any publication from the public portal for the purpose of private study or research.

- You may not further distribute the material or use it for any profit-making activity or commercial gain

- You may freely distribute the URL identifying the publication in the public portal.

If the publication is distributed under the terms of Article 25fa of the Dutch Copyright Act, indicated by the "Taverne" license above, please follow below link for the End User Agreement:

www.tue.nl/taverne

Take down policy

If you believe that this document breaches copyright please contact us at:

openaccess@tue.nl

providing details and we will investigate your claim. 


\title{
Overlapped Feeds to Increase the Edge of Coverage Gain in Multi-Beam Reflector Antennas
}

\author{
N. Llombart ${ }^{1}$, A. Neto ${ }^{1}$, G. Gerini ${ }^{1}$, M. Bonnedal ${ }^{2}$, and P. De Maagt ${ }^{3}$ \\ ${ }^{1}$ TNO Defence, Security and Safety, Den Haag, The Netherlands \\ ${ }^{2}$ Saab Space, Gothenburg, Sweden \\ ${ }^{3}$ ESTEC, European Space Agency, Noordwijk, The Netherlands
}

\section{Introduction}

The performances of focal plane arrays that implement multi-beam coverage from a single reflector antenna are usually reduced by conflicting requirements on the feed elements. Dense packing is required to minimize the beam separation, while typically large apertures provide the high feed directivity which in turn translates in low spill over losses from the reflector. In this contribution the use of a dielectric super-layer is proposed to shape the radiation pattern of each feed so that the spill over from the reflector is reduced without increasing the dimensions of each aperture. The shaping of the pattern is obtained with the excitation of a pair (TE/TM) of leaky waves. G. V. Trentini [1] was the first to propose the use of a partially reflecting screen to increase the directivity of single aperture. In [2] leaky waves were used to shape the radiation pattern of small antennas with the target of optimizing the efficiency of a center-fed reflector. Following the same design strategy, in the present contribution leaky waves are used in order to enhance the performances of each of the small feeds used in an array for multi beam reflector systems. Since the enhancement of multibeam antenna performances is a basic need for radiometric imaging arrays in the $\mathrm{mm}$ and sub-mm wave regimes but also for realistic next generation telecom systems, two feed array prototypes arranged in a hexagonal lattice have been designed and are being manufactured. The first one is of general applicability and assumes a worst case scenario with significant coupling between neighboring radiators. The second one focuses on a specific satellite telecommunication scenario and there the trade offs between the BW, the isolation of the beams and the efficiency drives the electrical design.

\section{System Parameters and Reference Array}

The generic scenario introduced in this section involves an area to be covered by independent beams, arranged in an hexagonal lattice and separated by an angle $\Delta \theta$. To achieve this coverage a corresponding hexagonal array placed in the focal plane of a parabolic reflector is considered, as shown in Fig. 1. The array elements are designed to be compatible with circular polarization in order to maintain the highest usability. The basic parameters characterizing an imaging system are: the beam separation $\Delta \theta$, the reflector diameter, $D$, and the focal distance, $F$ (see Fig. 1). $F / D$ defines the subtended angle $\theta_{s u b}$. All the power that is launched by the feed but is not intercepted by the reflector is effectively lost for the system (spill over). In order to enhance the spill over efficiency one would like to use directive feeds, however the dimensions of the apertures are limited by the period. For this reason most imaging systems need to perform a trade off between the efficiency with 


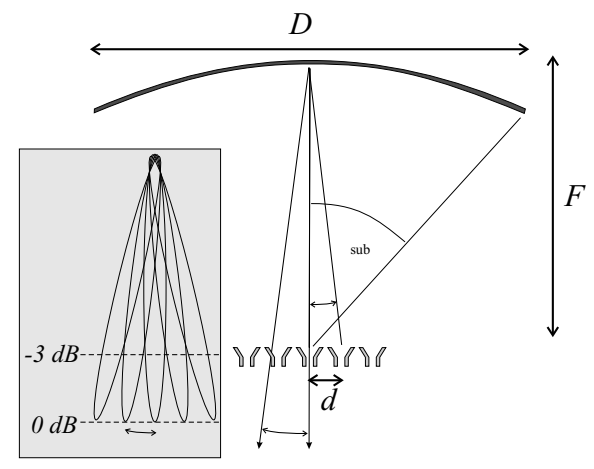

Figure 1: Schematic view of a multi-beam reflector system

which each element of the array excites the reflector and the capacity to sample the available field of view. In the following sections a single dielectric super-layer will be proposed to allow the overlap of equivalent apertures.

In order to establish a reference to which compare the performances of the leaky wave enhanced arrays, a standard waveguide array is investigated first, Fig. 2(a). It consists of an hexagonal grid array composed of 19 circular waveguide horns that open in an finite ground plane of dimensions $\left(12 \lambda_{0} \times 12 \lambda_{0}\right)$. To accurately

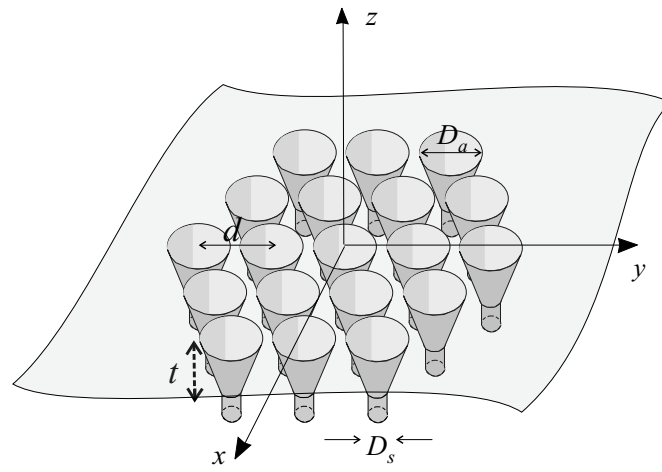

(a)

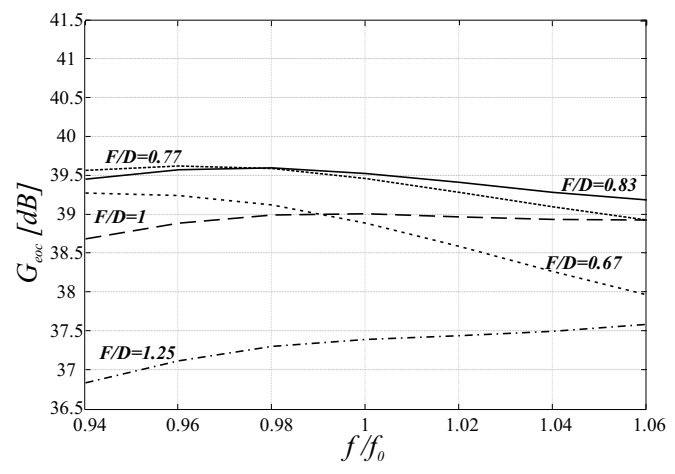

(b)

Figure 2: (a) Hexagonal grid array with periodicity $d=1.2 \lambda_{0}$ of circular metallic waveguide $D_{s}$ opening in a infinitely extended ground plane. The apertures $D_{a}=$ $1.1 \lambda_{0}$ fully sample the array. (b) Edge of coverage gain as a function of the frequency.

evaluate the performances of a reflector system fed by this reference array, the secondary patterns are obtained resorting to a one dimensional Physical Optics (PO) integration of the fields radiated by the reference array, which in turn have been calculated using CST Microwave Studio. The key merit parameter for these multibeam systems is the edge of coverage gain, which is defined at the cross over between three adjacent beams: $G_{e o c}=G(\Delta \theta / \sqrt{3})$. Figure 2(b) shows the edge of coverage gain for a reflector that provides $\Delta \theta \approx 1^{\circ}$, which corresponds to $F=66.66 \lambda_{0}$. 


\section{Waveguide Array Prototype}

When the distance between a dielectric super-layer and a ground plane is about half of a free space wavelength, leaky waves can propagate between the sandwiched area. The enhancement of the broadside directivity of a single antenna is obtained when the super-layer thickness is a quarter of the dielectric wavelength [3]. The proposed prototype is shown Fig. 3(a). The array is composed, like the reference array, by 19 waveguides, this time of square cross section with width, $w=0.67 \lambda_{0}$, and separation $d=1.2 \lambda_{0}$. Note that in this case the array of apertures does not fully occupy the central part of the ground plane. The dielectric constant of the slab is 4.5. The impact of the mutual coupling on the radiation patterns can be seen in Fig.

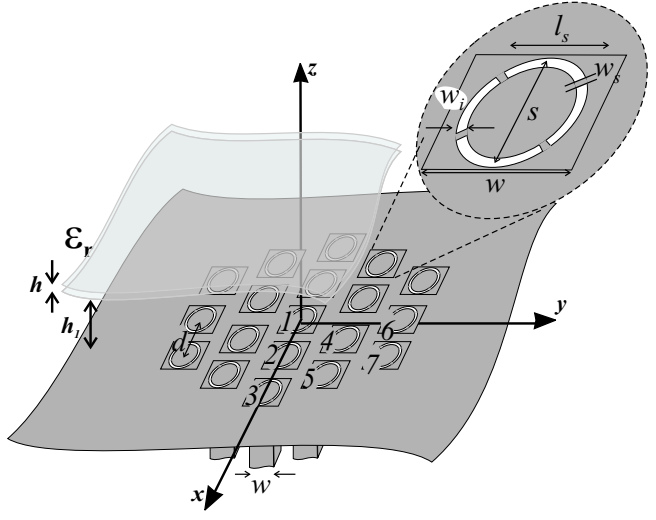

(a)

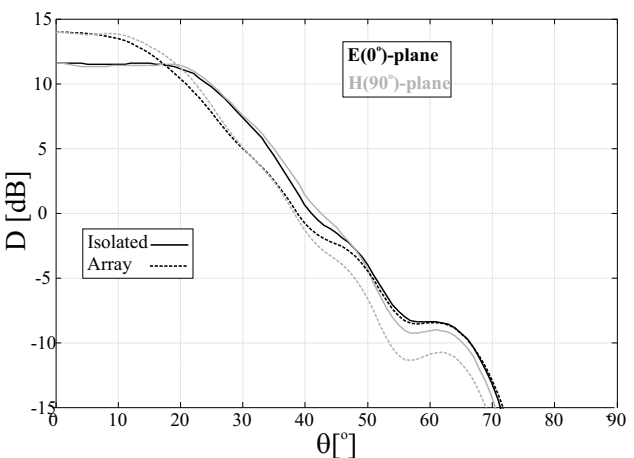

(b)

Figure 3: (a) Prototype waveguide array. The area of each unit cell is significantly larger than the dimension of each waveguide. (b) Amplitude of the calculated radiation patterns.

3(b). The calculated patterns are shown for the embedded and the isolated cases. The maximum directivity in the array environment is lower than the one obtained in isolation. That is because the distance between the array elements is such that the scattered field from the neighboring waveguides contributes almost out of phase with respect to the central element at broadside. While the embedded patterns are representative of the worst case scenario, the isolated patterns, in first approximation, can be representative of an ideal case, in which the adjacent waveguides are loaded with properly tuned reactive loads.

The worst case scenario corresponds to an imaging configuration in which the isolation between beams associated to adjacent wave-guides is not a driving parameters. For instance in radiometry at $\mathrm{mm}$ or sub-mm waves. A parametric study of the $G_{\text {eoc }}$ equivalent to of the reference array is plotted in Fig. 4. For all three $F / D$ the gain presents a weak frequency dependence. It is apparent that there is a significant improvement that can be as high as $1.7 \mathrm{~dB}$ for $F / D=0.67$.

For the best case a satellite based telecommunication scenario, in Ka band which 


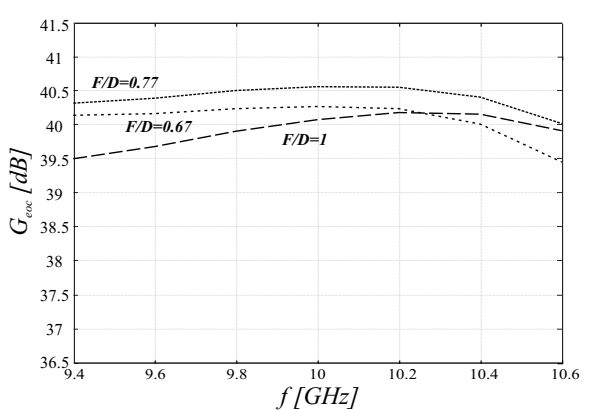

(a)

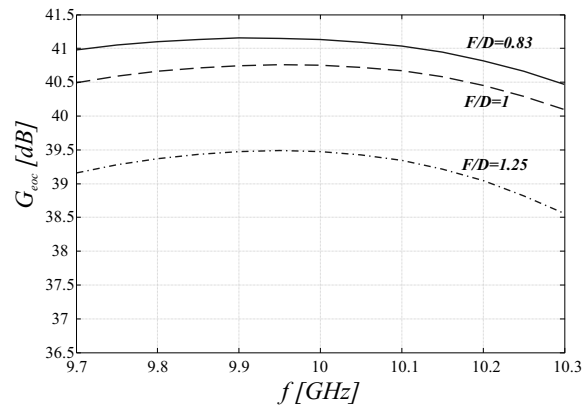

(b)

Figure 4: Edge of coverage gain calculated from the leaky wave feeds in the worst (a) and best (b) case scenarios.

makes use of two frequency bands and two linear polarizations to obtain independent, interleaved beams (separated by $1^{\circ}$ ) is imagined. The implementation of interleaved beams and of single aperture corresponding focal plane array is based on a 4 channel reuse scheme, with two linear polarizations (performed at the iris level) and two frequencies. The distance of the frequency filter from the aperture is tuned to achieve an effective short circuit at the aperture. The increase in edge of coverage in this second scenario (see Fig. (b)) is as high as high as $2.2 \mathrm{~dB}$, which essentially means that the no power is lost in spill over.

\section{Conclusions}

A novel strategy has been presented to design multi-beam reflector antenna system based on the excitation of a couple of leaky waves by covering the focal plane array with a single thin dielectric layer and tuning the array design to maximize their positive effect. In the worst case scenario of neighboring co-frequency and co-polarized beams an increase of the $G_{e o c}$ of $1 \mathrm{~dB}$ over a $6 \% \mathrm{BW}$ with respect to the standard free space designs could be obtained. In the scenario of a multi beam system for a telecommunication satellite with four channels an edge of coverage increase larger than $1.7 \mathrm{~dB}$ has been shown over a $3 \% \mathrm{BW}$.

\section{References}

[1] G.V. Trentini, "Partially reflecting sheet arrays", IEEE Trans. on AP, Vol.4, Iss.4, Oct. 1956, pp. 666- 671

[2] A. Neto, N. Llombart, G. Gerini, M. Bonnedal, P. De Maagt, "EBG Enhanced Feeds For High Aperture Efficiency Reflector Antennas", EuCAP 2006, Nice.

[3] D. R. Jackson, A. A. Oliner, "A Leaky-Wave Analysis of the High-Gain Printed Antenna Configuration", IEEE Trans. on AP, Vol. 36, no. 7, pp. 905-909, July 1988. 